\title{
Relationship between auditory discrimination of Serbian language phonemes and dysgraphia in different forms of written expression
}

\section{Vesela Milankov', Ivana Andjić', Jelena Vrućinić', Ljiljana Simić', Milica Stelkićn}

'University of Novi Sad, Faculty of Medicine, Department of Special Education and Rehabilitation, Novi Sad, Serbia

2Preschool institution "Neven", Priboj, Serbia

Primljen - Received: 08/06/2021

Prihvaćen - Accepted: 17/06/2021

\section{Corresponding author:}

Vesela Milankov, MD, PhD

Hajduk Veljkova 3, 21000 Novi Sad

vesela.milankov@mf.uns.ac.rs

Copyright: $\odot 2021$ Vesela Milankov et all. This is an Open Access article distributed under the terms of the Creative

Commons Attribution 4.0 International (CC BY 4.0) license.

\section{Summary}

Introduction. Writing is the most complex human ability and the most direct form of communication. Auditory discrimination is the ability to distinguish different sounds of language. After the age of seven, difficulties in auditory discrimination, even of similar sounds, are considered a pathological phenomenon. The aim of the research was to determine whether difficulties in auditory discrimination of phonemes are related to the manifestation of dysgraphia in children of younger school age.

Methods. The research was conducted at the Elementary School "Vuk Karadzić" in Priboj, during 2020, with the previous consent of the school principal, as well as the students' parents. The research sample included fifty children of the third and fourth grade, aged 9 and 10. For the purpose of this research, two tests were used: the Phonemic Discrimination Test (Kostić, Vladisavljević, Popović, 1983) and the Dysgraphic Handwriting Assessment Test (Ajuriaguerra, Auzias. 1971).

Results. There was no significant difference in achievement in the Phonemic Discrimination Test between boys and girls. Half of the tested students achieved the maximum score in the Phonemic Discrimination Test and they were fairly equal in their achievement in the Phonemic Discrimination Test. Girls generally had harmoniously developed handwriting, while more than half of the boys in the categories had inconsistent handwriting or dysgraphic handwriting when it came to the forms of dictation, free topic and transcription. No statistically significant correlations were found between the results in the Phonemic Discrimination Test and the Dysgraphic Handwriting Assessment Test, $\mathrm{p}>0.05$.

Conclusion. Based on the assessment of writing ability and auditory discrimination in young school children, no statistically significant association was found between auditory discrimination of sounds and manifestations of dysgraphic handwriting in all three forms of written expression (dictation, free topic, transcription).

Key words: students, writing, auditory discrimination, dysgraphia

\section{Introduction}

Communication is an essential part of human life and all living beings have the need to communicate [1,2]. Literature most often mentions the categorization of communication into verbal and nonverbal [3]. Verbal communication occurs in the forms of listening, speaking, reading and writing. It is considered to be the most successful mean of social influence as it can 
most completely express thoughts, the most diverse and complex contents and present the most complete and precise ideas and knowledge [4].

Writing is the most complex human ability which integrates almost all brain functions and it is more complex than reading. Today, writing is the most direct form of communication, despite the widespread use of technology [5]. Learning the writing process begins with visual, auditory and sensory-motor perception, but also by practicing graphic forms of letters within the acquiring alphabet. Basic skills needed to master writing are the differentiation of small muscles and the ability to control hand and finger movements, visuomotor integration, the ability to hold writing utensils, to perform basic strokes needed to draw a line, visual perception and discrimination, visual analysis of letters and words, as well as the orientation in space [6]. Mistakes that a child makes at the level of letters and syllables are omitting, moving, adding a superfluous letter or syllable, substituting and mixing, perseveration and anticipation [6,7]. Mistakes of incorrect disassembly and composition of words and disturbance of their boundaries, as well as errors at the sentence level indicate difficulties in individualizing separate words in oral speech. They are common in children with underdeveloped speech or with somewhat reduced cognitive abilities [8].

Auditory (phonemic) discrimination is the ability to distinguish the sounds of a particular language. It allows the child to distinguish the sounds from each other and to control the harmonization of his own sound production with the production of sounds from the speech environment $[5,9]$. It gradually develops at preschool age, and the ability to recognize sounds in words is a prerequisite for learning to read and write. These deficiencies in phonemic discrimination during period of phonological development may jeopardize the establishment and organization of spoken sounds. Based on this, it can be assumed that the voice production disorder is related to difficulties in phonemic discrimination $[9,10]$. After the age of seven, difficulties in auditory discrimination, even of similar sounds, are considered to be a pathological phenomenon. In a number of children, auditory discrimination and speech reproduction are endangered, which puts them at risk of social and academic difficulties. Detecting these difficulties as early as possible is of great importance because appropriate training can be organized for the children [10].

The aim of the study was to determine whether difficulties in auditory discrimination of phonemes are related to the manifestation of dysgraphia in children of younger school age. We hypothesized that students with detected difficulties in auditory discrimination would be more likely to have dysgraphic handwriting in all forms of written expression.

To our knowledge, this is the first study in Serbian language that examines the possible connection between these variables.

\section{Methods}

The research was conducted in the elementary school "Vuk Karadzic" in Priboj, during 2020 , with the previously obtained consent of the school principal.

The research sample included fifty children of the third and fourth grade, of which 28 were male and 22 were female. The age of the respondents was nine and ten.

The criteria for inclusion in the research were average intellectual abilities and signed parental consent. All students were tested before starting school. The use of this data was approved by the school principal, as well as the students' parents who confirmed that by giving their written consent. Available data in students were whether their achievement on the test was below average, average or above average. The study inclusion criteria involved 
students with IQ of 90 and $>90$. Children who had below-average achievement when enrolling in school did not take this test included in the study.

The writing test was conducted in class, for all students at the same time. The students were first explained the examination procedure. Every student was given a sheet of paper without lines and a pencil with a task to write the text at the dictation of the examiner. The text was dictated at a rhythm appropriate for the age of the children. After finishing writing dictation, the students were tasked with writing an essay on an agreed topic. The final task was to copy the previously dictated text.

The Phonemic Discrimination Test was done individually with each student, in a separate room as it was necessary to isolate the student from all distractors. The Phonemic Discrimination Test lasted for about 15 minutes, while the Dysgraphic Handwriting Assessment Test, for all three forms of written expression, lasted about 30 minutes. Before administering each test, students were given detailed instructions, with the possibility of asking the examiner for additional clarifications.

Two tests were used for the purposes of this research:

1. Phonemic Discrimination Test (Kostić, Vladisavljević, Popović, 1983) - The Phonemic Discrimination Test aims to determine the extent to which respondents of certain age have the ability to discriminate sounds. This test consists of pairs of cards, containing images of objects whose names have a very similar sound context. The differences are usually in one phoneme. The test is composed of 20 pairs of cards - objects, including words with phonemes whose distinctive characteristics are very similar to each other. They do not include all sounds, but only those which are more difficult to discriminate at these developmental ages. The examiner shows two pictures to students while saying the name of the object from one of those pictures. The student is asked to show the object whose name he has just uttered. If the student does the task correctly, he gets one point, if he makes a mistake, he does not get any points. The total number of points is 40 . The average score is between 20 and 30 points. Above the average is between 30 and 40 points. The examination is individual [11].

2. Dysgraphic Handwriting Assessment Test (Ajuriaguerra, Auzias, 1971) aims to detect dysgraphia in written text. It contains 25 features, divided into three groups. The first group consists of seven features identifying poor spatial organization of the handwriting as a whole, the second group has thirteen features that represent clumsy spelling, and the third group consists of five features assessing errors in the form and proportions of letters. During the scoring, $0,0.5$ or 1 point can be given for each feature. The obtained point is multiplied by the coefficient given with each feature. The quality of the handwriting is assessed based on the total number of points. A score below 10 indicates harmoniously developed handwriting, a score between 10 and 13.5 indicates inconsistent/difficult to read handwriting, a score between 14 and 18 points represents dysgraphic handwriting, and a score of 19 or more points is an indicator of expressed dysgraphic handwriting [12].

The results were recorded for each child individually, after which the analysis of the obtained data was conducted.

Descriptive statistics was used in the analysis and description of the obtained data, while for the variables that were quantitatively expressed (results in the Phonemic Discrimination Test and the Dysgraphic Handwriting Assessment Test) it was determined that the assumption of normal distribution of results (Kolmogorov-Smirnov test) was not met. A nonparametric Mann-Whitney U test was applied to analyze the differences between boys and girls, as well as between students of third and fourth grade. The Spearman correlation 
coefficient was used to determine the relationship between the two tests. The results are presented in tables. Statistical processing and analysis was done using SPSS ver. 20

\section{Results}

The research included 50 students, of which 28 were boys (56\%) and 22 were girls (44\%).

Of the entire sample, $66 \%$ of students were in the third grade, while $34 \%$ of students attended the fourth grade.

Based on the results shown in Table 1, it can be seen that there is no difference in achievement in the test between boys and girls. Fourth graders scored slightly better compared to third graders.

Half of the tested students achieved the maximum score in the Phonemic Discrimination Test, $8 \%$ had a score of 39 , and every fourth the score of 38 . About $15 \%$ of students scored 37 or less points, with a minimum score of 32. The average number of points in the test is 38.8 , with the standard deviation of 1.7 , which has shown that there were no substantial deviations, or that the students achieved fairly similar results in the Phonemic Discrimination Test.

It can be noticed that girls generally have harmoniously developed handwriting, while
Table 1. Descriptive statistics in the Phonemic Discrimination Test in relation to gender and grade

\begin{tabular}{lcccccc}
\multirow{2}{*}{ Gender } & & N & MIN & MAX & Mean & SD \\
& boys & 28 & 32 & 40 & 38.8 & 1.8 \\
\multirow{4}{*}{ Grade } & girls & 22 & 34 & 40 & 38.8 & 1.7 \\
& third & 33 & 32 & 40 & 38.5 & 1.8 \\
& fourth & 17 & 34 & 40 & 39.4 & 1.5 \\
\hline
\end{tabular}

N-number of subjects, MIN-minimum score, MAX-maximum score, Mean-arithmetic mean, SD-standard deviation

more than half of the boys in the categories have inconsistent or dysgraphic handwriting when it comes to the form of dictation (Table 2).

In terms of grades, dysgraphia is more present in younger students, and it is absent in fourth grade students.

Two thirds of students (66\%) showed harmoniously developed handwriting on dictation, $16 \%$ showed inconsistent handwriting, while every tenth student had dysgraphic handwriting. Distinctly dysgraphic handwriting was found in $8 \%$ of students. So, a third of students had a problem with handwriting. The average score on this test is 9.8, with the standard deviation of 5.3.

Based on the results shown in Table 3, it can be seen that girls generally have harmoniously developed handwriting in the form

Table 2. Distribution of students in the Dysgraphic Handwriting Assessment Test in relation to gender and grade (form of dictation)

\begin{tabular}{|c|c|c|c|c|c|c|}
\hline \multicolumn{2}{|c|}{ Dictation } & \multirow{2}{*}{$\begin{array}{c}\begin{array}{c}\text { Harm. } \\
\text { dev. } \\
\text { handwr. }\end{array} \\
13\end{array}$} & \multirow{2}{*}{$\begin{array}{c}\text { Inconsist./ illeg. } \\
\text { handwr. } \\
6\end{array}$} & \multirow{2}{*}{$\begin{array}{c}\text { Dysgr. } \\
\text { handwr. } \\
5\end{array}$} & \multirow{2}{*}{$\begin{array}{c}\text { Dist. dysgr. } \\
\text { handwr. } \\
4\end{array}$} & \multirow{2}{*}{$\begin{array}{c}\text { Total } \\
28\end{array}$} \\
\hline & boys & & & & & \\
\hline Gentict & girls & 20 & 2 & 0 & 0 & 22 \\
\hline \multirow{2}{*}{ Grade } & third & 21 & 3 & 5 & 4 & 33 \\
\hline & fourth & 12 & 5 & 0 & 0 & 17 \\
\hline
\end{tabular}

Harm. dev. handwr. - Harmoniously developed handwriting; Inconsist. / illeg. handwr. - Inconsistent/illegible handwritng; Dysgr. handwr. - Dysgraphic handwriting; Dist. dysgr. handwr. - Distinctly dysgraphic handwriting 
Table 3. Distribution of students in the Handwriting Dysgraphic Handwriting Assessment Test in relation to gender and grade (form - free topic)

\begin{tabular}{|c|c|c|c|c|c|c|}
\hline Free topic & & $\begin{array}{l}\text { Harm. dev. } \\
\text { handwr. }\end{array}$ & $\begin{array}{l}\text { Inconsist./ } \\
\text { illeg. handwr. }\end{array}$ & $\begin{array}{c}\text { Dysgr. } \\
\text { handwr. }\end{array}$ & $\begin{array}{l}\text { Dist. dysgr. } \\
\text { handwr. }\end{array}$ & Total \\
\hline \multirow{2}{*}{ Gender } & boys & 13 & 6 & 6 & 3 & 28 \\
\hline & girls & 19 & 3 & 0 & 0 & 22 \\
\hline \multirow{2}{*}{ Grade } & third & 20 & 4 & 6 & 3 & 33 \\
\hline & fourth & 12 & 5 & 0 & 0 & 17 \\
\hline
\end{tabular}

of free composition, while more than half of the boys in the categories have inconsistent handwriting or dysgraphia. In terms of grades, dysgraphia is more present in younger students, while it is absent in fourth grade students.

About two thirds of students showed harmoniously developed handwriting in the form of writing on a free topic, $18 \%$ of them have inconsistent, and $12 \%$ of students dysgraphic handwriting. Distinctly dysgraphic handwriting was found in $6 \%$ of students. The average score in this test is 10 , with the standard deviation of 4.9. Therefore, the variability of results is high among students.

Based on the results shown in Table 4, it can be seen that girls generally have harmoniously developed handwriting, while more than half of the boys in the categories have inconsistent handwriting or dysgraphia in the form of transcription. In terms of grades, dys- graphia is more present in younger students, while it is absent in fourth grade students.

About two thirds of students showed harmoniously developed handwriting, $14 \%$ of them inconsistent, and $12 \%$ dysgraphic handwriting in the form of transcription. Distinctly dysgraphic handwriting was found in $6 \%$ of students. The average score in this test is 9.7, with the standard deviation of 5.3, indicating high variability of results.

No statistically significant correlations were found between the results in the Phonemic Discrimination Test and the Dysgraphic Handwriting Assessment Test (dictation, free topic, transcription), since Sig. $>0.05$.

The Mann-Whitney U test found no statistically significant difference in the results of the Phonemic Discrimination Test between boys $(\mathrm{Md}=39.50, \mathrm{~N}=28)$ and girls $(\mathrm{Md}=40.00$, $\mathrm{N}=22), \mathrm{U}=296.000, \mathrm{Z}=-0.258, \mathrm{p}=0.797$.

Table 4. Distribution of students on the Handwriting Dysgraphia Assessment Test in relation to gender and grade (form - transcription)

\begin{tabular}{|c|c|c|c|c|c|c|}
\hline \multicolumn{2}{|c|}{ Transcription } & \multirow{2}{*}{$\begin{array}{c}\begin{array}{c}\text { Harm. } \\
\text { dev. } \\
\text { handwr. }\end{array} \\
14\end{array}$} & \multirow{2}{*}{$\begin{array}{c}\begin{array}{c}\text { Inconsist./ } \\
\text { illeg. } \\
\text { handwr. }\end{array} \\
5\end{array}$} & \multirow{2}{*}{$\begin{array}{c}\begin{array}{c}\text { Dysgr. } \\
\text { handwr. }\end{array} \\
6\end{array}$} & \multirow{2}{*}{$\begin{array}{c}\text { Dist. dysgr. } \\
\text { handwr. } \\
3\end{array}$} & \multirow{2}{*}{$\begin{array}{r}\text { Total } \\
28\end{array}$} \\
\hline & boys & & & & & \\
\hline Gender & girls & 20 & 2 & 0 & 0 & 22 \\
\hline \multirow{2}{*}{ Grade } & third & 22 & 2 & 6 & 3 & 33 \\
\hline & fourth & 12 & 5 & 0 & 0 & 17 \\
\hline
\end{tabular}




\section{Discussion}

This research focused on examining the association between auditory discrimination of phonemes and the manifestation of dysgraphia in younger school children. The percentage of children with writing difficulties varies in range. In our research, the largest number of children in the third and fourth grade had writing abilities on average, while the smallest number of children demonstrated very superior writing abilities. 50 students of the third and fourth grade participated in the research, $56 \%$ of them were boys and $44 \%$ of them were girls.

Auditory discrimination is considered to be very important in the initial stages of writing and reading acquisition, while more complex processes (meaning, syntactic structure and context) begin to dominate later on. The tasks of auditory discrimination assess the ability to recognize the distinctive features of sounds, in isolation and in short words $[13,14]$. Our research showed that in auditory discrimination, as many as half of the tested students achieved the maximum score on the test, $8 \%$ of them achieved the score of 39 , and every fourth the score of 38 . About $15 \%$ of the students scored 37 or less points, with a minimum score of 32 . No differences were observed in relation to gender, and fourth-graders showed significantly better results than third-graders in the test. However, according to Gligorović et al. (2011), the analysis of the relationship between the gender of the subjects and the achievement in speech comprehension assessment tasks showed that boys were significantly more successful than girls in the areas of auditory discrimination [15].

A study examining the link between phonological disorders and auditory discrimination showed that boys had a higher percentage of unsatisfactory results in the auditory discrimination test. Also, it was confirmed that the age of children affects the maturation of abilities necessary for sound differentiation $[16,17]$.

In the Dysgraphic Handwriting Assessment Test, the children worked on three forms of writing: dictation, transcription and free composition on an agreed topic. All three forms included different modalities. Text dictation and transcription are based on auditory control (as well as physiologically healthy hearing), visual and graphomotor skill, phonemic awareness (the discrimination of voiced and unvoiced and acoustically similar phonemes), established linguistic basis as well as writing speed. Free composition on a given topic presupposes certain knowledge, which a child should demonstrate through a given topic. Difficulties occur in those who have not mastered the technique of writing, do not have sufficiently developed language structures, vocabulary and syntax. This test showed that two thirds of students had harmoniously developed handwriting, and the rest of them had difficulties with handwriting (12\% of students had dysgraphia). Girls mostly had harmoniously developed handwriting, while more than half of the boys had dysgraphic handwriting. As for the grade, dysgraphia was more present in younger students, while it was absent in fourth grade students, which is understandable and shows that older students have reached a satisfactory level of skills through practice.

In comparison to other studies, we have observed somewhat higher frequency of dysgraphia in children of younger school age. It can be speculated that there is an increase of dysgraphia prevalence in population of this age, but follow-up studies are needed. $[5,13,18]$.

It has also been proven that students with dysgraphic handwriting often show resistance toward writing and therefore, poorer results when it comes to mastering this skill [19].

The claim that children who exhibit difficulties in auditory discrimination of sounds have a higher number of writing errors proved to be incorrect in our research. No statistically significant associations were found between auditory discrimination and the occurrence of dysgraphia. What we noticed during the 
research was that the most common type of writing errors, related to auditory discrimination, was the omission of graphemes. The study conducted by Duranović et al. (2017) on mistakes and creativity in writing included 59 students of the third and fourth grade of an elementary school in Tuzla. The most common type of writing errors in students of that age was the omission of graphemes [18]. The assumption that children with developmental dysgraphia have spelling problems in addition to handwriting problems is confirmed by a study showing that children with dysgraphic handwriting make significantly more mistakes at the level of words and sentences (phonological and lexical mistakes) compared to their peers of typical development. In addition to omitting graphemes in words, children with dysgraphic handwriting showed significantly more errors in copying already written content, as well as replacing already written content with other words and sentences $[20,21]$.

Results show that errors in auditory discrimination and writing are more common in boys of younger school age. Studies conducted by Calasan et al. also show that writing errors are more dominant in boys. A study regarding the effect of writing disorders on school success in students with dysgraphia included 461 students of the third, fourth and fifth grades of three city schools on the territory of the Republic of Srpska. Results show the presence of dysgraphia in schoolage children, significantly more common in boys than in girls [22]. Our results showed that girls generally had harmoniously developed handwriting, while more than half of the boys were in the categories of inconsistent handwriting or dysgraphia. Concerns regarding the existing differences between boys and girls are one of the main topics of the study of the impact of gender differences on student writing [23]. Encouraged by the results of the research, teachers' attitudes towards girls having a greater interest in writing and reading can lead to an unfavorable position of boys in the school grading system. This problem can be solved by adjusting the requirements of the teaching process as recommended by experts. Some of these recommendations stem from studies showing that boys are more successful at writing assignments if they are not required to write texts that are too long, as well as if the structure of the written assignment is clear [13].

The analysis of the obtained data showed that third grade students had dysgraphia in the form of dictation, transcription and writing on a free topic. In fourth grade students, there were no elements of dysgraphia in these writing tasks. From that we can conclude that age has a significant impact on the reduction of dysgraphic errors in students. In one of the studies concerning the frequency of mistakes in the use of morphological forms during writing in younger school age students, the authors characterized the period between the first and second grade as very important for acquiring knowledge about the written language. Namely, the second grade children had significantly fewer errors in writing morphological word forms compared to the first grade children. The author believes that this period may be a part of the normal language knowledge consolidation process, since a higher degree of fluency and productivity during writing was found in the second grade children [24].

Research results of some authors speak in favor of high correlation between the ability to read and write, which leads us to the conclusion that these two abilities have much in common. However, by thorough consideration it can be concluded that writing is far more demanding than reading. One of the reasons for this conclusion concerns the interpretation of the importance of orthographic rules necessary when writing. During reading, it is necessary to recognize the visual representation of words and connect them with meaning, but since the orthographic representation must be completely invoked from the mental lexicon, writing is a more complex function [25]. 


\section{Conclusion}

Based on the assessment of writing ability and auditory discrimination in children of younger school age, it was determined that there was no statistically significant correlation between auditory discrimination of sounds and manifestation of dysgraphic handwriting in all three forms of written expression (dictation, free topic, transcription).

The most common type of writing errors associated with auditory discrimination errors is the omission of graphemes.

Funding source. The authors received no specific funding for this work.

Ethical approval. The Ethics Committee of the Faculty of Medicine, University of Novi Sad, approved the study and informed consent was obtained from all the individual re-

\section{References:}

1. Jovanović N, Slavnić S. Atipičan jezički razvoj. Beograd. Društvo defektologa Srbije. 2009.

2. Halliday MAK. Learning how to mean. In E.H. Lennenberg \& E. Lennenberg (Eds.). Foundations of language development (Vol.1). New York: Academic Press. 1995.

3. Marot D. Uljudnost u verbalnoj i neverbalnoj komunikaciji. FLUMINENSIA: časopis za filološka istraživanja 2005;17(1):53-70.

4. Medwell J, Wray D. Handwriting: What do we know and what do we need to know? Literacy 2007;41(1):10-5.

5. Nicolson RI, Fawcett AJ. Dyslexia, dysgraphia, procedural learning and the cerebellum. Cortex 2011;47(1):117-27.

6. Taur S, Karande S, Saxena AA, Gogtay NJ, Thatte UM. Use of Computerized Tests to Evaluate Psychomotor Performance in Children with Specific Learning Disabilities in Comparison to Normal Children. Indian J Med Res 2014;140(5):644-8
Boys make more mistakes in auditory discrimination tasks and writing in all forms of written expression.

To our knowledge, there were no studies that compared the same variables in the Serbian-speaking area. The limitation of the study is that a small sample of students was included. Future research, in addition to a larger number of respondents, should also include younger students. Also, the presence of speech and language disorders, as well as learning disabilities, must be taken into account.

spondents. The research was conducted according to the Declaration of Helsinki.

Conflicts of interest. The authors declare no conflict of interest.

7. Nikčević Milković A. Psihologija pisanja određenje područja, motivacija, samoregulacija, poučavanje, metode istraživanja, esejsko ispitivanje. Zadar: Odjel za nastavničke studije Sveučilišta u Zadru, 2009.

8. Rosenberg, S. The Language of the mentaly retarded: Development, processes and intervention. In S. Rosenberg (Ed.), Handbook of applied psycholinguistics: Major thrusts of research and theory. Hillsdale, New Jersey: Eralbum, 2002.

9. Blaži D, Arapović D. Artikulacijski Nasuprot Fonološkom Poremećaju. Govor 2003;20(12):27-38.

10. Blaži D, Vancaš M, Jakovac Prizl T. Fonološki poremećaji i fonemska diskriminacija u predškolske djece. Hrvatska revija za rehabilitacijska istraživanja 2000;36(2):165-8.

11. Kostić Đ, Vladisavljević S. Test za ispitivanje govora i jezika. Zavod za udžbenike i nastavna sredstva Beograd, 1983. 
12. Povše Ivkić V. Praktikum opšte defektološke dijagnostike. Beograd. Institut za mentalno zdravlje, 2000.

13. Rosenblum S, Aloni T, Josman N. Relationships between handwriting performance and organizational abilities among children with and without dysgraphia: a preliminary study. Res Dev Disabil 2010;31(2):502-9.

14. Overvelde A, Hulstijn W. Handwriting development in grade 2 and grade 3 primary school children with normal, at risk, or dysgraphic characteristics. Res Dev Disabil 2011;32(2):540-8.

15. Gligorović M, Radić Šestić M. Odnos između nivoa razvoja sposobnosti neophodnih za uspešno ovladavanje akademskim veštinama i pola kod dece sa specifičnim smetnjama $u$ učenju. Nastava i vaspitanje 2011;1:145-56.

16. Nakeva von Mentzer C. Phonemic discrimination and reproduction in 4-5-year-old children: Relations to hearing. Int J Pediatr Otorhinolaryngol 2020;133:109981.

17. Alloway TP, Gathercole SE, Pickering SJ. Verbal and visuospatial short-term and working memory in children: are they separable? Child Dev 2006;77(6):1698-716.

18. Duranović M. Spelling errors of dyslexic children in Bosnian language with transparent orthography. J Learn Disabil 2017;50(5):591-601.

19. Bambaeeroo F, Shokrpour N. The impact of the teachers' non-verbal communication on success in teaching. J Adv Med Educ Prof 2017;5(2):51-9.

20. Berninger VW, Nagy W, Beers S. Child writers' construction and reconstruction of single sentences and construction of multi-sentence texts: Contributions of syntax and transcription to translation. Read Writ 2011;24(2):151-82.

21. Berninger VW, Abbott RD, Swanson HL, Lovitt D, Trivedi P, Lin SC, et al. Relationship of word-and sentence-level working memory to reading and writing in second, fourth, and sixth grade. Lang Speech Hear Serv Sch 2010;41(2):179-93.

22. Ćalasan S, Vuković M, Mastilo B, Vuković B, Bakoč A, Zečević I. Uticaj tipa poremećaja pisanja na školski uspjeh učenika sa disgrafijom. Biomedicinska istraživanja 2017;8(2):136-43.

23. Rosenblum S. Inter-relationships between objective handwriting features and executive control among children with developmental dysgraphia. PLOS One 2018;13(4):e0196098.

24. Manis FR, Seidenberg MS, Doi L. M. Rapid naming and the longitudinal prediction of reading subskills in first and second graders. Scient Stud Read 1999;3(2):129-57.

25. Milankov V. Deficit fonološke svesnosti kod dece sa disleksijom i disortografijom -doktorska disertacija. Univerzitet u Novom Sadu. Novi Sad. Medicinski fakultet. 2016. 


\title{
Povezanost auditivne diskriminacije fonema srpskog jezika i disgrafije kod različitih formi pismenog izražavanja
}

\author{
Vesela Milankov ${ }^{1}$, Ivana Anđić ${ }^{2}$, Jelena Vrućinić ${ }^{1}$, Ljiljana Simić ${ }^{1}$, Milica Stelkić \\ 'Univerzitet u Novom Sadu, Medicinski fakultet, \\ Katedra za specijalnu edukaciju i rehabilitaciju, Novi Sad, Srbija \\ ${ }^{2}$ Predškolska ustanova „Neven", Priboj, Srbija
}

Uvod. Pisanje je najsloženija ljudska sposobnost i predstavlja najneposredniji oblik komunikacije. Auditivna diskriminacija je sposobnost razlikovanja glasova jezika. Nakon sedme godine teškoće u auditivnoj diskriminaciji, čak i sličnih glasova, smatraju se patološkom pojavom. Cilj istraživanja bio je da utvrdimo da li su poteškoće u auditivnoj diskriminaciji fonema povezane sa ispoljavanjem disgrafije kod dece mlađeg školskog uzrasta.

Metode. Istraživanje je sprovedeno u Osnovnoj školi „Vuk Karadžić" u Priboju, tokom 2020. godine uz prethodno dobijenu saglasnost direktora škole, kao i roditelja učenika. Uzorak istraživanja obuhvatio je pedesetoro dece trećeg i četvrtog razreda, uzrasta 9 i 10 godina. Za potrebe ovog istraživanja koristila su se dva testa, Test fonemske diskriminacije (Kostić Đ, Vladisavljević S, Popović M, 1983) i Test za procenu disgrafičnosti rukopisa (Ajuriaguerra, Auzias, 1971).

Rezultati. Nije ispoljena razlika u postignuću na testu auditivne diskriminacije između dečaka i devojčica. Polovina ispitivanih učenika postiže maksimalan skor na testu auditivne diskriminacije i prilično su ujednačeni u postignuću na testu auditivne diskriminacije fonema. Devojčice uglavnom imaju skladno razvijen rukopis, dok je više od polovine dečaka u kategorijama neskladan rukopis ili disgrafičan rukopis kada se radi o formi diktata, slobodnog sastava i prepisa. Nisu utvrđene statistički značajne povezanosti između rezultata na testu fonemske diskriminacije i testa za procenu disgrafičnosti rukopisa, $\mathrm{p}>0,05$.

Zaključak. Na osnovu procene sposobnosti pisanja i auditivne diskriminacije kod dece mlađeg školskog uzrasta utvrđeno je da ne postoji statistički značajna povezanost između auditivne diskriminacije glasova i ispoljavanja disgrafičnosti rukopisa u sve tri forme pisanog izražavanja (diktat, slobodna tema, prepisivanje).

Ključne reči: auditivna diskriminacija, učenici, pisanje, disgrafija 